\title{
Infiltrating Bladder Urothelial Carcinoma with Glandular Differentiation
}

National Cancer Institute

\section{Source}

National Cancer Institute. Infiltrating Bladder Urothelial Carcinoma with Glandular

Differentiation. NCI Thesaurus. Code C39817.

An invasive transitional cell carcinoma of the bladder that exhibits glandular

differentiation. 